Каспарова М.А. Сточные воды, поступающие с территории Махачкалы, - источник загрязнения акватории Каспийского моря

УДК 504.4:543.3

DOI: $10.21779 / 2542-0321-2018-33-4-107-113$

\title{
M.A. Kacnapoвa
}

\section{Сточные воды, поступающие с территории Махачкалы, - источник загрязнения акватории Каспийского моря}

Дагестанский государственный университет; Россия, 367001, 2. Махачкала, ул. М. Гаджиева, 43a; m_kasparova76@mail.ru

Объектами исследования являлись пробы неочищенных сточных вод, поступающих в акваторию Каспийского моря с территории г. Махачкалы. Применением флуориметрического метода определено содержание органических загрязняющих веществ в сточных водах, отобранных в период с февраля по май 2018 года. Выявлено, что основными загрязнителями, содержащимися в сточных водах, являются синтетические поверхностно-активные вещества, фенолы и нефтепродукты.

Ключевые слова: сточные воды, Каспийское море, фенолы, нефтепродукты, синтетические поверхностно-активные вещества.

\section{Введение}

Каспийское море - крупнейший на Земле замкнутый водоём. Его углеводородные ресурсы и биологические богатства не имеют аналогов в мире $[1,2]$.

Проблема Каспийского моря на сегодняшний день очень актуальна для всех пяти государств бассейна Каспийского моря: Азербайджана, России, Казахстана, Ирана и Туркменистана [3]. Вне зависимости от того, как решится вопрос о международноправовом статусе Каспия и о разделении нефтяных ресурсов между прикаспийскими государствами, Каспий остается общим экологическим объектом региона.

Экологические проблемы Каспийского моря связаны с загрязнением вод в результате добычи и транспортировки нефти на континентальном шельфе, поступлением загрязняющих веществ из Волги и других рек, впадающих в Каспийское море, жизнедеятельностью прибрежных городов.

Западно-Каспийский район в пределах административных границ Республики Дагестан с впадающими реками (Терек, Сулак, Самур и др.) является одним из самых высокопродуктивных на Каспии. Здесь расположены основные миграционные пути, а также происходят воспроизводство и нагул осетровых, лососевых, полупроходных видов рыб, морских и проходных сельдей, обыкновенной кильки и др.

Мониторинг состояния морской воды в прибрежной зоне Каспийского моря в пределах Республики Дагестан показал, что хотя качество морской воды с 2014 по 2016 годы по санитарно-химическим показателям требований СанПиН 2.1.5.2582-10 «Санитарно-эпидемиологические требования к охране прибрежных вод морей от загрязнения в местах водопользования населения» несколько улучшилось, уровни бактериального загрязнения воды в зонах рекреации (пляжные зоны) превышают гигиенические нормативы в десятки и сотни раз [4]. 
Каспарова М.А. Сточные воды, поступающие с территории Махачкалы, - источник загрязнения акватории Каспийского моря

Основным источником бактериального загрязнения морской воды является непрекращающийся сброс в море неочищенных коммунально-бытовых канализационных и ливневых стоков. По данным государственной статистической отчетности «2ТПводхоз», ежегодно в Каспийское море с территории Республики Дагестан сбрасывается около 80 млн м ${ }^{3}$ загрязненных сточных вод (CB) и около 100 тыс. тонн загрязняющих веществ [5]. Значительный объем неочищенных $\mathrm{CB}$ в Каспийское море поступает с территории г. Махачкалы $[6,7]$.

Статья посвящена определению содержания органических загрязняющих веществ (O3B) в СВ Махачкалы. Представлены результаты оценки СВ, поступающих в акваторию Каспийского моря с территории г. Махачкалы, по санитарно-химическим показателям качества.

\section{Экспериментальная часть}

Объектами исследования являлись стоки неочищенных вод, которые формируются за счет городских промышленных, коммунально-хозяйственных и дождевых вод. Пробы отбирались в период с февраля по май 2018 года в пределах Махачкалы.

Водосток у лечебно-оздоровительного комплекса «Бельй медведь» формируется за счет городских коммунально-хозяйственных, промышленных и дождевых вод. Примерный расход составляет $0,74 \mathrm{~m}^{3} / \mathrm{c}$ (рис. 1$)$.

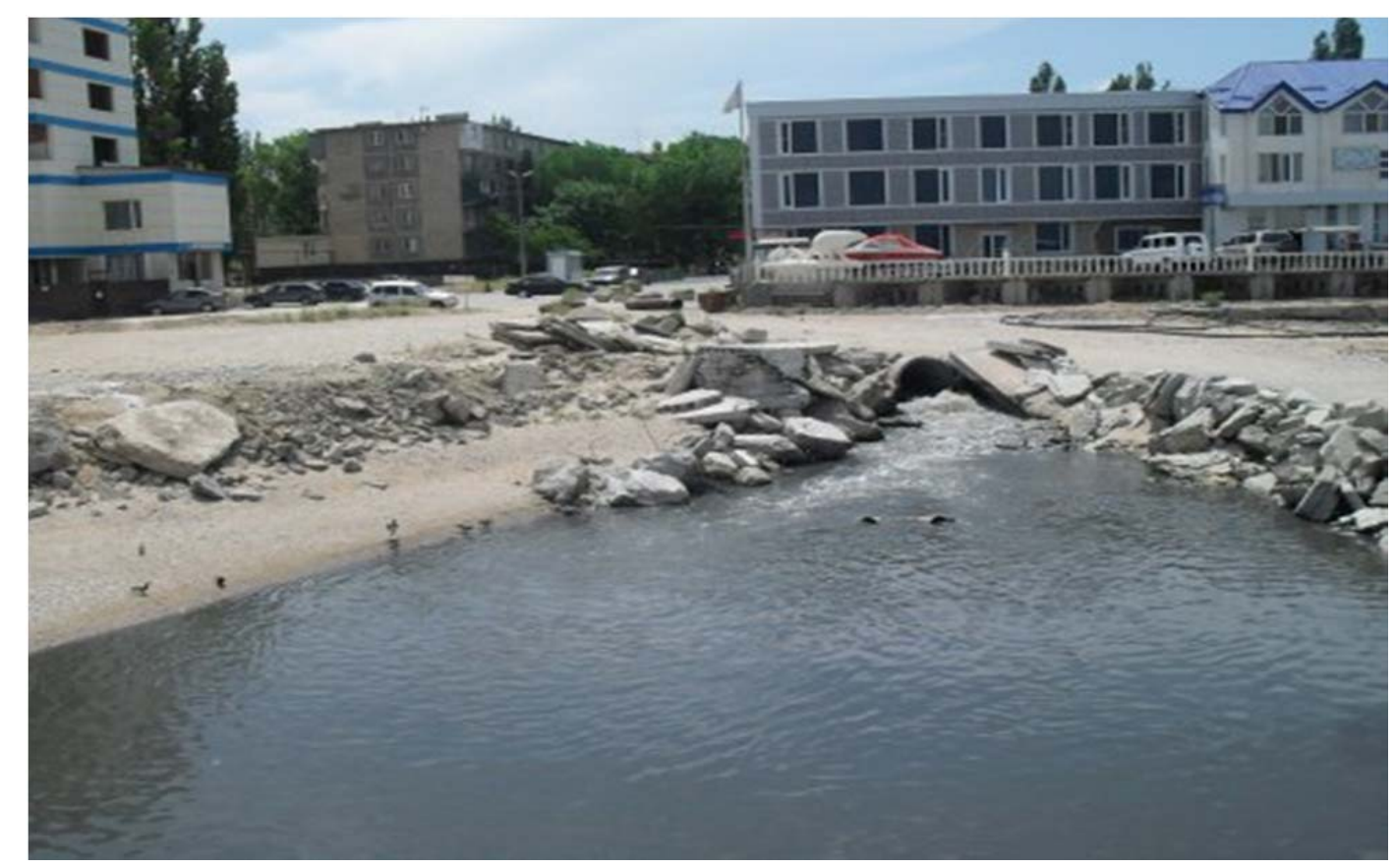

Рис. 1. Сточные воды у лечебно-оздоровительного комплекса «Белый медведь» (ЛОК «БМ»), март 2018 г.

Водосток у лечебно-трудового профилактория формируется за счет городских коммунально-хозяйственных, промышленных и дождевых вод. Примерный расход составляет $0,34 \mathrm{~m}^{3} / \mathrm{c}$ (рис. 2). 
Каспарова М.А. Сточные воды, поступающие с территории Махачкалы, - источник загрязнения акватории Каспийского моря

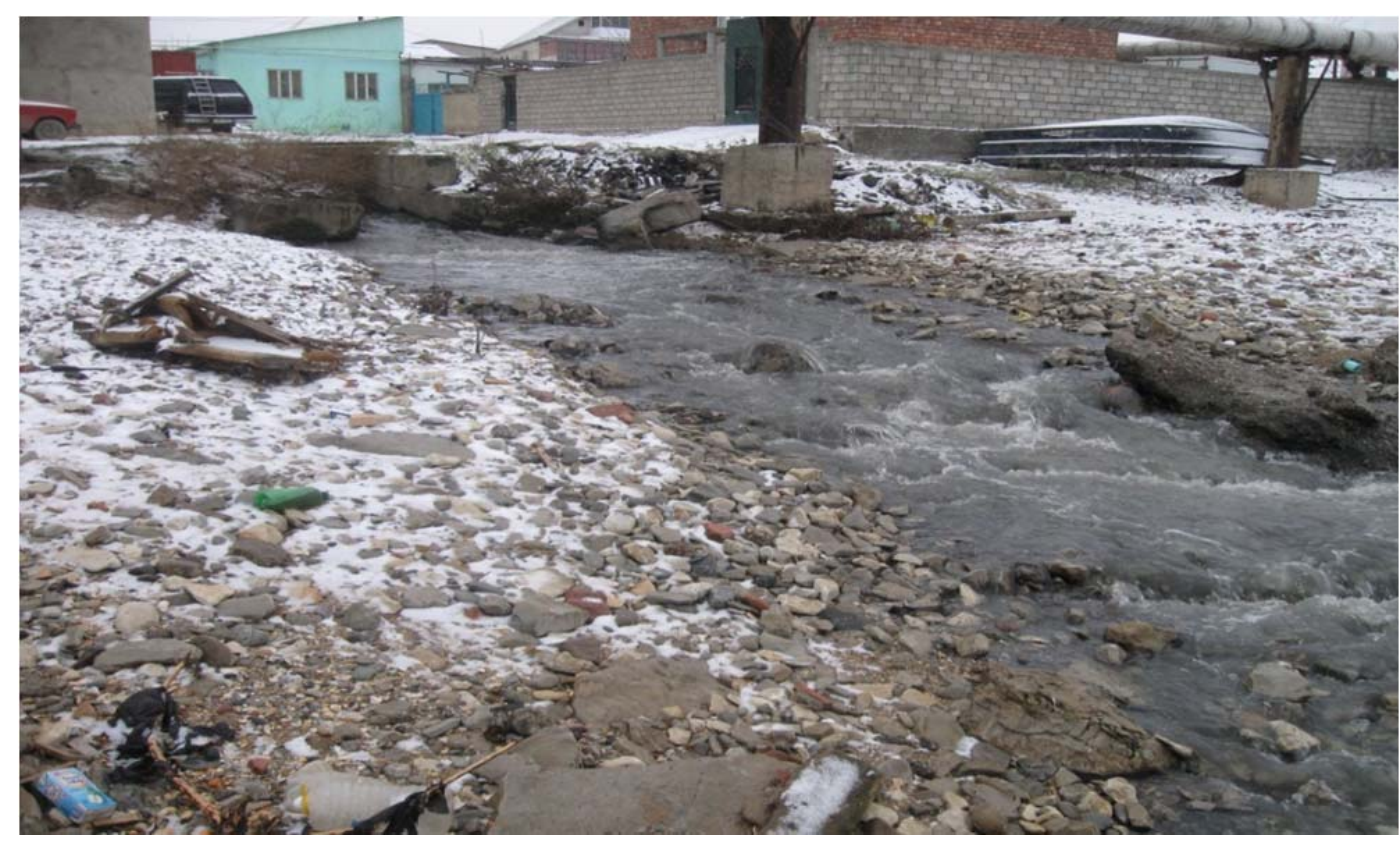

Рис. 2. Сточные воды у лечебно-трудового профилактория (ЛТП), февраль 2018 г.

В формировании стока речки Тернаирка-Воняйка участвуют в основном сточные воды Тернаирского геотермального месторождения, городские и дачные стоки, дождевые и грунтовые воды. Среднегодовой расход составляет $0,5 \mathrm{~m}^{3} / \mathrm{c}$ (рис. 3).

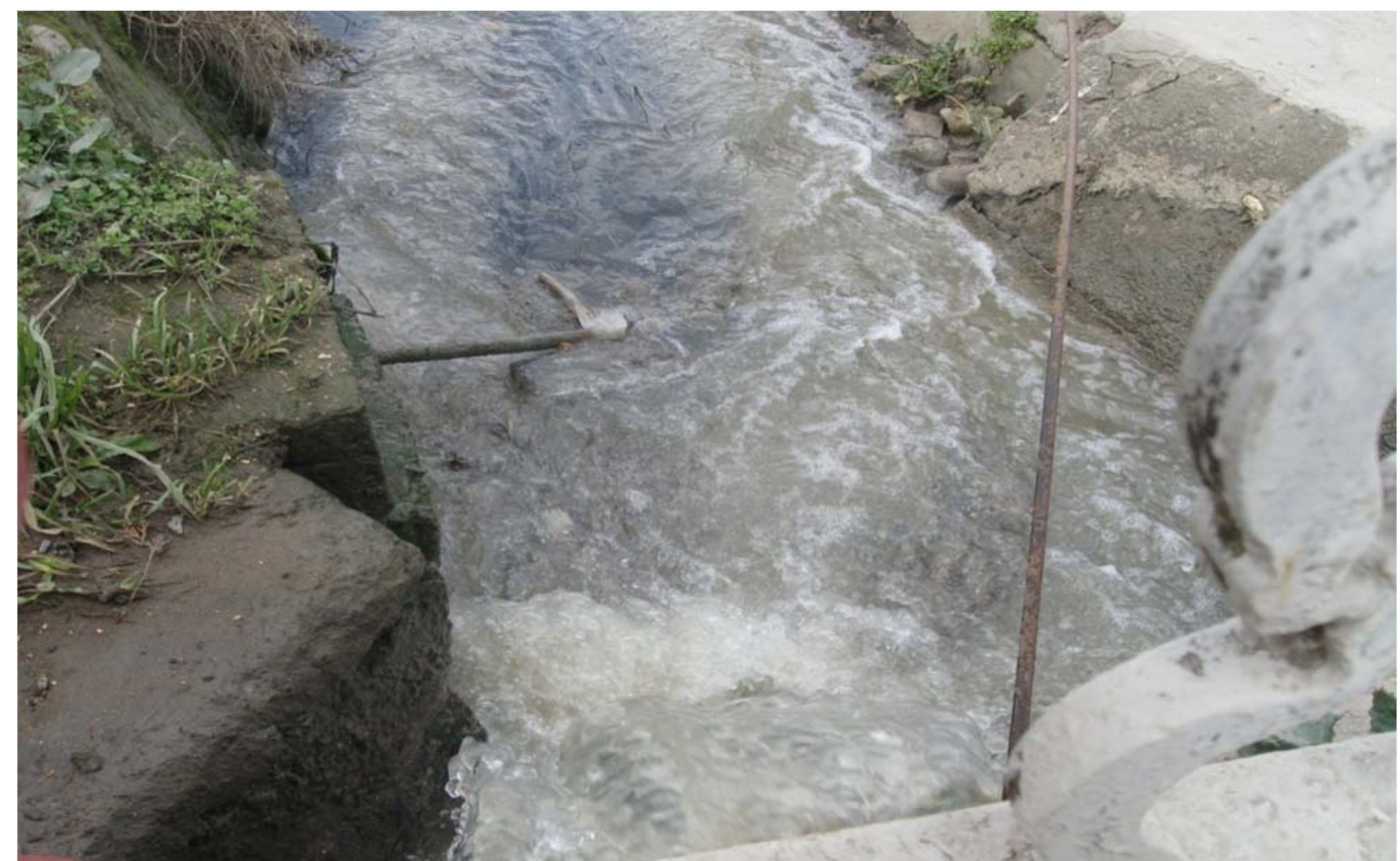

Рис. 3. Речка Тернаирка-Воняйка у моста шоссе Аэропорт, февраль 2018 г.

Отбор проб СВ осуществляли в соответствии с требованиями Международной организации по стандартизации (ИСО) по методике «Руководство по отбору сточных вод» ИСО 5667-10 [8]. 
Каспарова М.А. Сточные воды, поступающие с территории Махачкалы, - источник загрязнения акватории Каспийского моря

Определение величины $\mathrm{pH}$ воды проводили потенциометрическим методом на pH-метре $\mathrm{pH}-150$ МИ. Соленость исследуемых проб вод устанавливали определением сухого остатка. Массовую концентрацию нефтепродуктов, фенолов, синтетических поверхностно-активных веществ (СПАВ), общее содержание органических веществ (ХПК) определяли флуориметрическим методом [9, 10] на анализаторе жидкости «Флюарат-02-3М» с термореактором «ТЕРМИОН».

\section{Результаты и их обсуждение}

Из данных, представленных в табл. 1, следует, что СB, поступающие в Каспийское море с территории г. Махачкалы, по показателям температуры, $\mathrm{pH}$, щелочности и солености соответствуют нормативным требованиям.

По общему содержанию фенолов все пробы СВ не соответствуют нормативным требованиям, и превышение предельно допустимых концентраций (ПДК) составляет от 17 до 260 раз. Максимальное содержание фенолов зарегистрировано в пробе СВ речки Тернаирка-Воняйка, отобранной в феврале 2018 года: оно превышает ПДК в 260 раз, что, по-видимому, связано со сбросом в водосток отработанных фенолсодержащих термальных вод. Высокие концентрации фенолов зарегистрированы и в пробах СВ, отобранных с водостоков у лечебно-трудового профилактория (ЛТП) и лечебнооздоровительного комплекса «Белый медведь» (ЛОК «БМ»): превышение ПДК составляет от 114 до 240 и от 151 до 171 раза соответственно.

Содержание нефтепродуктов в анализируемых пробах СВ колеблется в пределах от 0,16 до 0,52 мг/дм³. Наиболее загрязненными нефтепродуктами являются СВ: речки Тернаирка-Воняйка - 8,2-10,0 ПДК; водостока ЛТП - 7-10,4 ПДК; водостока ЛОК «Белый медведь» - 3,2-9,2 ПДК.

Все отобранные пробы содержат высокие концентрации синтетических поверхностно-активных веществ (СПАВ) - 2,9-14,1 мг/дм³ ${ }^{3}$ что превышает ПДК в 29-141 раз. Наиболее загрязненными оказались пробы CB, отобранные с водостока у ЛТП: превышение ПДК в 81-141 раз.

Таблица 1. Химические показатели проб сточных вод, отобранных в феврале-мае 2018 г. в г. Махачкале

\begin{tabular}{|c|c|c|c|c|c|c|c|c|c|c|}
\hline \multirow{4}{*}{ Показатель } & \multicolumn{9}{|c|}{ Объект исследования } & \multirow{4}{*}{ ПДК* } \\
\hline & \multirow{2}{*}{\multicolumn{3}{|c|}{$\begin{array}{c}\text { Тернаирка-Воняйка } \\
\text { Дата отбора }\end{array}$}} & \multirow{2}{*}{\multicolumn{3}{|c|}{$\frac{\text { ЛТП }}{\text { Дата отбора }}$}} & \multirow{2}{*}{\multicolumn{3}{|c|}{$\begin{array}{l}\text { ЛОК «БМ» } \\
\text { Дата отбора }\end{array}$}} & \\
\hline & & & & & & & & & & \\
\hline & $\begin{array}{l}\infty \\
\stackrel{\infty}{i} \\
\stackrel{d}{\beth}\end{array}$ & $\begin{array}{l}\stackrel{\infty}{\cdots} \\
\hat{0} \\
\dot{j}\end{array}$ & $\begin{array}{l}\infty \\
\vec{\not} \\
0 \\
\dot{ \pm}\end{array}$ & 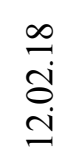 & $\begin{array}{l}\infty \\
\stackrel{\infty}{0} \\
\stackrel{0}{0}\end{array}$ & $\begin{array}{l}\infty \\
\ddot{0} \\
\dot{\Xi}\end{array}$ & $\begin{array}{l}\infty \\
\stackrel{\infty}{i} \\
\stackrel{0}{i} \\
\end{array}$ & 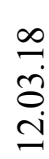 & $\begin{array}{l}\infty \\
\stackrel{\infty}{*} \\
\ddot{0} \\
\dot{I}\end{array}$ & \\
\hline $\begin{array}{l}\text { Температу- } \\
\text { pa, }{ }^{\circ} \mathrm{C}\end{array}$ & 8 & 21 & 22 & 8 & 21 & 24 & 12 & 19 & 20 & - \\
\hline $\mathrm{pH}$ & 7,5 & 7,8 & 7,8 & 7,5 & 7,5 & 7,5 & 7,3 & 7,2 & 7,1 & $6,5-8,5$ \\
\hline $\begin{array}{l}\text { Солёность, } \\
\text { мг/дм }{ }^{3}\end{array}$ & 750 & 566 & 583 & 451 & 520 & 508 & 233 & 341 & 245 & - \\
\hline $\begin{array}{l}\text { Щёлочность, } \\
\text { мГ-экв/дм }{ }^{3}\end{array}$ & 5,0 & 4,2 & 4,7 & 3,9 & 3,9 & 4,0 & 5,5 & 5,2 & 5,4 & - \\
\hline $\begin{array}{l}\text { ХПК, } \\
\text { мгО/ дм } 3\end{array}$ & 50 & 59 & 73 & 70 & 69 & 70 & 53 & 54 & 57 & 30 \\
\hline
\end{tabular}


Каспарова М.А. Сточные воды, поступающие с территории Махачкалы, - источник загрязнения акватории Каспийского моря

\begin{tabular}{|l|c|c|c|c|c|c|c|c|c|c|}
\hline $\begin{array}{l}\text { Фенолы, } \\
\text { мг/ дм }\end{array}$ & 0,260 & 0,017 & $\begin{array}{c}0,02 \\
7\end{array}$ & 0,240 & 0,114 & 0,121 & 0,151 & 0,163 & 0,171 & 0,00 \\
\hline $\begin{array}{l}\text { НП, } \\
\text { мг/ дм }\end{array}$ & 0,47 & 0,50 & 0,41 & 0,35 & 0,52 & 0,47 & 0,16 & 0,46 & 0,46 & 0,05 \\
\hline $\begin{array}{l}\text { СПАВ, } \\
\text { мг/ дм }\end{array}$ & 0,48 & 0,70 & 0,42 & 12,0 & 8,1 & 14,1 & 0,58 & 0,72 & 0,29 & 0,1 \\
\hline
\end{tabular}

*ПДК - для водоемов рыбохозяйственного назначения.

По содержанию растворенных органических веществ (ХПК) к сильно загрязненным можно отнести все пробы CB, отобранные в период с февраля по май (табл. 1).

В табл. 2 представлены результаты расчета среднемесячного содержания органических загрязняющих веществ в сточных водах г. Махачкалы, отобранных в февралемае 2018 года (через дробь для сравнения приведены результаты 2012 года) [10].

Таблица 2. Среднемесячное содержание органических загрязняющих веществ в сточных водах г. Махачкалы, отобранных с февраля по май 2018 г.

\begin{tabular}{|l|c|c|c|c|}
\hline \multirow{2}{*}{$\begin{array}{c}\text { Объект исследо- } \\
\text { вания }\end{array}$} & \multicolumn{4}{|c|}{ Содержание, мг/дм ${ }^{3}$} \\
\cline { 2 - 5 } & Фенолы & НП & СПАВ & ХПК \\
\hline $\begin{array}{l}\text { СВ речки Тер- } \\
\text { наирка-Воняйка }\end{array}$ & $0,162 / 0,008$ & $0,46 / 0,23$ & $5,3 / 3,4$ & 61 \\
\hline СВ у ЛТП & $0,158 / 0,011$ & $0,45 / 0,14$ & $11,4 / 10,0$ & 70 \\
\hline СВ у ЛОК «БМ» & $0,101 / 0,010$ & $0,36 / 0,16$ & $5,3 / 8,6$ & 55 \\
\hline ПДК & 0,001 & 0,05 & 0,1 & 30 \\
\hline
\end{tabular}

Из данных, приведенных в табл. 2, следует, что в 2018 году по сравнению с 2012 г. загрязненность СВ речки Тернаирка-Воняйка, у ЛТП, у ЛОК «БМ» увеличилась: по фенолам - в 20,14 и 10; по нефтепродуктам - в 2, 3 и 2 раз, соответственно. Содержание СПАВ в СВ речки Тернаирка-Воняйка увеличилось в 1,5 раза, в СВ у ЛТП - в 1,1 раза, в СВ у ЛОК «БМ» уменьшилось в 1,6 раза.

Данные, приведенные в табл. 2, использованы для расчета примерного количества органических загрязняющих веществ, поступающих в Каспийское море с исследуемыми водостоками в течение года.

В табл. 3 представлены результаты расчета количества ОЗВ, поступающих в Каспийское море в течение года за счет исследуемых водостоков.

Таблица 3. Количество (тонн) органических загрязняющих веществ, поступающих в Каспийское море с водостоками в течение года

\begin{tabular}{|l|c|c|c|c|c|}
\hline \multicolumn{1}{|c|}{ Объект исследования } & $\begin{array}{c}\text { Расход, тыс. } \\
\text { м³/год }\end{array}$ & Фенолы & НП & СПАВ & ОВ* \\
\hline $\begin{array}{l}\text { СВ речки Тернаирка- } \\
\text { Воняйка }\end{array}$ & 15768000 & 2,554 & 7,253 & 83,57 & 361 \\
\hline СВ у ЛТП & 10722240 & 1,694 & 4,825 & 122,23 & 282 \\
\hline СВ у ЛОК «БМ» & 27121640 & 2,739 & 9,764 & 143,74 & 559 \\
\hline Всего & 53611880 & 6,987 & 21,842 & 349,54 & 1202 \\
\hline
\end{tabular}

*OB - общее содержание органических веществ в пересчете с ХПК. 
Каспарова М.А. Сточные воды, поступающие с территории Махачкалы, - источник загрязнения акватории Каспийского моря

\section{Заключение}

Из представленных в табл. 3 результатов видно, что только по исследуемым водостокам с территории Махачкалы в Каспийское море поступает ежегодно более 53,6 млн м ${ }^{3}$ СВ, содержащих 1202 т высокотоксичных органических веществ. Основными загрязнителями СВ являются синтетические ПАВ и нефтепродукты. Наиболее загрязненными оказались СВ водостока у лечебно-оздоровительного комплекса «Белый медведь», затем СВ речки Тернаирка-Воняйка и водостока у ЛТП. Источниками этих загрязняющих веществ, по-видимому, являются коммунально-бытовые стоки, геотермальные воды, различные мойки, которых в Махачкале огромное количество.

\section{Литература}

1. Каспийское море. Энциклопедия / И.С. Зонн и др. - 2-е изд., доп. и перераб. М.: Восточная книга, 2013. - 558 с. - ISBN 978-5-7873-0732-0.

2. Иванов В.П. Рыбы Каспийского моря (систематика, биология, промысел). Астрахань: Изд-во АГТУ, 2012. - 226 с.

3. Каспий: международно-правовые документы / Сост.: С.С. Жильцов, И.С. Зонн, А.Г. Костяной, А.В. Семенов. - М.: Международные отношения, 2018. 568 c. - ISBN 978-5-7133-1617-4.

4. О состоянии санитарно-эпидемиологического благополучия населения в Республике Дагестан в 2016 году: Государственный доклад. - Управление Федеральной службы по надзору в сфере защиты прав потребителей и благополучия человека по Республике Дагестан, 2017. - 144 с.

5. Доклад об экологической ситуации в Республике Дагестан за 2010 г. - URL: https://pandia.ru/text/78/324/53040.php.

6. Каспарова М.А., Рамазанов А.Ш., Сараева И.В. Гидрохимическая оценка качества морских вод в административных границах г. Махачкалы // Вестник Дагестанского государственного университета. - 2014. - Вып. 1. - С. 172-178.

7. Рамазанов А.Ш., Каспарова М.А., Сараева И.В. Оценка качества сточных вод в пределах г. Махачкалы по химическим показателям // Юг России: экология, развитие. - 2014. - Т. 31, № 2 (31). - С. 139-146.

8. Фомин Г.С. Вода. Контроль химической, бактериальной и радиационной безопасности по международным стандартам. Энциклопедический справочник. 3-е изд., перераб. и доп. - М.: Протектор, 2000. - 848 с.

9. Методические указания по измерению массовой концентрации нефтепродуктов флуориметрическим методом в пробах питьевой воды и воды поверхностных и подземных источников водопользования. МУК 4.1.068 - 96.

10. Методические указания по измерению массовой концентрации фенолов общих и летучих флуориметрическим методом в пробах питьевой воды и воды поверхностных и подземных источников водопользования. МУК 4.1.069 - 96.

Поступила в редакиџю 28 ноября 2018 г. 
Каспарова М.А. Сточные воды, поступающие с территории Махачкалы, - источник загрязнения акватории Каспийского моря

UDC 504.4:543.3

DOI: $10.21779 / 2542-0321-2018-33-4-107-113$

\section{Waste water from Makhachkala pollute the Caspian Sea}

\section{M.A. Kasparova}

Dagestan State University; Russia, 367001, Makhachkala, M. Gadzhiev st., 43a; m_kasparova76@mail.ru

The objects of the research were tests of untreated wastewater coming to the water area of the Caspian Sea from the territory of Makhachkala. Using the fluorometric method, the content of highly toxic organic pollutants in wastewater collected within the period from February to May 2018 was determined. It was revealed that the main pollutants contained in wastewater are synthetic surfactants, phenols and petroleum products.

Keywords: waste water, the Caspian Sea, synthetic surfactants, phenols, petroleum products.

Received 28 November, 2018 